\title{
INFORMATION AND COMMUNICATION TECHNOLOGIES: USE BY COMPANIES IN THE REPUBLIC OF SERBIA
}

\author{
Maja Kljajić ${ }^{*}$ \\ Marko Pavićević, \\ Maja Obradović, \\ Ana Obradović
}

\section{Singidunum University,} Belgrade, Serbia

\begin{abstract}
:
In modern business conditions, development of information and communication technologies leads to everyday changes in a way of doing business in different industry sectors. Information and communication technologies include elements and skills which are oriented toward information and its creation, transmission and data storage. Relevance of previously mentioned technology can be noticed in reduce of money, time and etc. The importance of the development of the domestic digital society was also recognized by the state through the definition of the Strategy for the development of the information society in the Republic of Serbia until 2020. The strategy deals with issues related to the development of the digital society in the country. Report contains results regarding the use of information and communication technologies in operations of corporations during 2019 and 2020, which is published in Republic Bureau of Statistics. Based on those results, it has been concluded that there is tendency of growth when it comes to the use of information and communication technologies in the business operations of companies in Republic of Serbia. According to mentioned, there are data that indicate that hundred percent of companies use internet connection, there is increase in use of web sites and active use of portable devices with noticeable growth over the years.
\end{abstract}

Keywords:

ICTs, Digitalization, Cloud, COVID-19, Enterprises.
Correspondence:

Maja Kljajić

e-mail:

mkljajic@singidunum.ac.rs

\section{INTRODUCTION}

Fast development of information and communication technologies (hereinafter ICT) lead companies to more efficient everyday operations, in a way of reducing money, time, energy and etc. In the global development agenda named Serbia and Agenda2030 [1] it is being highlighted that Serbia is in the process of developing ICT, which worsened the position of international competitiveness. The initial assumption is that ICT has become a key factor for successful adaptation of companies to new business conditions, especially in times of pandemic caused by the COVID-19 virus. According to [2] information technologies, information systems and business applications became key factors for successful adaptation of organizations to new business conditions. 
Use of ICT in everyday business operations brings major reduce of different resources by reducing time that is necessary to conduct business operations, as well as reducing complex bureaucracies. Furthermore, it increases quality of products and services and improves relations between companies and external business entities. Also, it is pointed out that today the application of ICT is inevitable for companies because the use of these technologies is so widespread that if the company does not use them, it negatively affects its competitiveness in the market, which can jeopardize its survival.

The fourth industrial revolution, ICT had enormous impact on development of digitalization [3]. Therefore, digitalization is becoming the main initiator of innovation, modernization, economic growth, competitiveness and comprehensive socio-economic progress and development. Nevertheless, global pandemic created environment where companies are orienting their business practices in a completely digital manner, due to completely changed way of life and business practices [4]. When it comes to new market conditions caused by the emergence of a global pandemic caused by COVID-19, great success has been achieved by companies that have managed to adapt their business procedures and practices. Effective reaction to new circumstances is another important element. Companies that have managed to successfully implement their business processes and convert them to online mode in short period of time have achieved good results. When it comes to the economy of the Republic of Serbia, many positive changes took place during the time of global pandemic. There is increasing number of eGovernment users and the importance of the existence of platform have been particularly evident in the previous period. The eGovernment portal was created by the Government of the Republic of Serbia with the idea of providing the citizens of the Republic of Serbia with faster and easier access to a large number of administrative tasks without physically going to various state institutions [5]. This was significant during the initial enforcement of measures that were need to comply with and referred to the measures of social distancing, reducing the number of people who are able to be present in certain area, etc. The analysis of the "Digital Serbia" initiative, shows that every third company in the Republic of Serbia accelerated the work on digitalization during the COVID-19 pandemic, even though less business activities in many areas has been performed [6].

\section{TYPES OF CONTENT}

Digitalization represents the use of existing technologies and information to improve or replace business processes, creation of profit and creation of environment for digital business in which information plays crucial role. On the other hand, digital transformation was defined as the integration of digital technologies in all areas of business that are the cause of fundamental changes in the way of doing business and the process of delivering value to customers [7]. The comprehensive use of digital technologies that fundamentally transform business models, completely change business processes. Beside the radical transformation in organization, digital transformation has a huge impact on the economy, government and society.

Therefore, the digital transformation represents unique evolution that will bring changes and growth in all business areas if it is used correctly and all opportunities that are being provided over time, while reducing the negative effects of all the challenges it can bring [8]. Also, it is important to mention that the digitalization of business processes has contributed to higher productivity, automatization processes, business control, data analysis, security of data storage as well as lowering operating costs and less possibility of errors in business processes. Aim of digitalization is being noticed in the use of advanced technology in business processes in corporations, in order to achieve capital market competitiveness [9].

The key elements of business digitalization are reflected in the following [10]:

- Cloud technology, which is one of the key elements in the process of improving the level of competitiveness in the market, optimizing costs and improving overall business efficiency. It enables central data storage, control of data access, easier retrieval of required documents and information, easier report writing and data security. It is crucial to indicate that main use of cloud technology is data centralization. According to Flexera report, research indicate that there is an increase of use of cloud technology, more than expected and reason behind it is restrictions made by COVID-19 during 2020. Furthermore, results indicate that up to $92 \%$ of surveyed companies use some form of cloud technology. Thereby, large companies are in the lead in terms of strategic planning and the amount of budget they allocate for the implementation of cloud 
solutions in the future [11]. Research has shown that cloud alternatives can contribute to increasing productivity levels in the range between 35\% and $40 \%$, and that collaboration and cooperation via cloud technologies can increase the efficiency of internal business operations by as much as $90 \%$. Cloud technology is available today in the following three different forms: public cloud, private cloud and hybrid cloud [12].

- Digital documents, in comparison with traditional paper documents, provide all data in digital format, which significantly reduces the cost of creating, sending and archiving documents. One of the key features of digital documents, in comparison with traditional documents, is their potential for automatic processing, because they can be generated and transferred automatically and directly from the sender to receiver.

- Data security - comparing with local servers, cloud technology offers more advanced level of security, because data has been stored off-site, in another word, the data is never in one place, which eliminates possibility of losing data. From the aspect of data security, certain individuals and some company departments can be banned from accessing the servers. Any changes in document, including opening and editing is usually registered in the activity $\log$ so all changes and who made them can be tracked all times [10].

\section{USE OF INFORMATION AND COMMUNICATION TECHNOLOGIES IN COMPANIES}

Statistical Office of the Republic of Serbia monitors the development and use of ICT in companies and households. In the continuation of this paper, an overview of ICT trends from the aspect of companies operating in the Republic of Serbia will be presented. Statistical Office of the Republic of Serbia has issued a publication entitled as Use of Information and Communication Technologies in the Republic of Serbia, 2020 , on the basis of which information regarding the work of enterprises during the reporting period will be presented. Previously mentioned research was conducted in march 2020 based on telephone interview. The sample included 1,571 companies operating in the territory of the Republic of Serbia and the response rate was $80.60 \%(1,270$ enterprises) [13]. In order to compile the sample, classification of legal entities was conducted on the following basis:
- Small sized entities (10-49 employees): 583;

- Middle sized entities (50-249 employees): 424;

- Large sized entities (250+ employees): 263.

Due to unusual circumstance during 2020 as a result of COVID-19 where companies had to modify their business practices, the results show that in the Republic of Serbia, $100 \%$ of companies have an Internet connection. However, due to the introduction of a state of emergency during 2020, the Government brought a Decree on organizing the work of employers during a state of emergency, which organized work from home. In this regard, the results of the analysis showed that $81 \%$ of households in the Republic of Serbia have an Internet connection, which is an increase of almost $1 \%$ compared to 2019. Furthermore, it is important to indicate that $97,8 \%$ of households with income over 600 euros owns internet connection. From the aspect of computer usage, the number of users increased by almost 2\% compared to 2019.

From the aspect of mobile internet usage for business practices, analysis shows that during $2020,77 \%$ of companies use a mobile internet connection through portable devices, such as: smartphones, laptops, tables and etc. According to the size of legal entities, use of portable devices for mobile internet connection is mainly used by large entities with a share of $91.1 \%$.

During 2020, $84.4 \%$ of companies own website, which is an increase of almost 1\%, compared to 2019. When it comes to the structure of companies by size, analysis shows the following results:

- Small size entities: $82,8 \%$;

- Medium size entities: $89,1 \%$;

- Large size entities: $95 \%$.

In regard to e-commerce, during 2019, 27.9\% of companies in the Republic of Serbia, places their products and services via the Internet. When it comes to the structure of companies by size, analysis shows the following results:

- Small size entities: $28,1 \%$;

- Medium size entities: $30,2 \%$;

- Large size entities: $14,7 \%$.

During 2019, there was an increase of electronic invoices that were being automatically processed, and in regard to this, the analysis shows the following results when it comes to the structure of companies by size small: $18.8 \%$, medium: $18.1 \%$ and large: $30.7 \%$. On the other hand, the share of electronic invoices sent electronically, which are not suitable for automatic processing, was much higher, small: $68.9 \%$, medium: $69.8 \%$ and large: $89.1 \%$. 
However, it must be noted that the largest number of invoices are still issued in paper form, where small legal entities have participation of $98.8 \%$, medium entities have participation of $97.4 \%$ and large entities have participation of $100 \%$.

\section{USAGE OF CLOUD SERVICES}

As previously mentioned, cloud is synonym for availability, speed and efficient data management. They also include ICT services that are accessed via the Internet for the purpose of using software, storage space and etc.

Main features of cloud services:

- They are located on the servers of service providers;

- Can be used at the request of users;

- They are paid based usage space capacity.

From the aspect of cloud usage service, Statistical Office of the Republic of Serbia displays following data.

Exactly $18.6 \%$ of companies in the territory of Republic of Serbia pay for cloud services via the Internet. From the aspect of company structure by size, the analysis displays following results:

- Small size entities: $15.4 \%$;

- Medium size entities: $29.1 \%$;

- $\quad$ Large size entities: $33.6 \%$.

Cloud services that are being used over the Internet are as follows:

1) Email:
a) Small size entities: $78.1 \%$;
b) Medium size entities: $80.00 \%$;
c) Large size entities: $78,1 \%$.

2) Office software
a) Small size entities: $65,6 \%$;
b) Medium size entities: $81,50 \%$;
c) Large size entities: $73,1 \%$

3) Hosting database of legal entities:
a) Small size entities: $58,9 \%$;
b) Medium size entities: $65,70 \%$;
c) Large size entities: 50,3\%.

4) File storage:

a) Small size entities: 50,30\%;

b) Medium size entities: 58,70\%;

c) Large size entities: $48,90 \%$.
5) Software applications:
a) Small size entities: $53,70 \%$;
b) Medium size entities: $45,10 \%$;
c) Large size entities: $37,30 \%$.

6) Customer relationship management (CRM) software applications for customer information management:
a) Small size entities: $23,10 \%$;
b) Medium size entities: $21,80 \%$;
c) Large size entities: $24,60 \%$.

7) Computer power to operate and manage software used by a legal entity:
a) Small size entities: $21,30 \%$;
b) Medium size entities: $26,80 \%$;
c) Large size entities: $24,90 \%$.

Medium and large entities are at the forefront in terms of strategic planning and the amount of budget they allocate for the implementation of cloud solutions in future business practices. Also, when it comes to cloud services, it is important to note that there are numerous benefits, such as efficiency and flexibility of business practices, increased availability and security of data (better security of IT systems), availability of various options (public, private and hybrid cloud), cost optimization, increased productivity and time management.

\section{ICT EXPERTS AND TRAINING}

The term information and communication technology imply various elements and features for creating, storing and transmitting information. However, crucial element in the field of information and communication technology is the staff, which are call ICT experts, such as developers, system analysts and designers [2]. According to [4] there is increase in number of experts in the field of ICT, as well as their demand in the domestic and international labour market.

Based on the previously conducted analysis of the ICT usage in companies in Serbia, it can be concluded that there is an upward tendency of usage of ICT in company operations. Companies employed $19.3 \%$ of ICT professionals during 2020. In terms of size, large entities employ $69.2 \%$ of ICT professionals, while small entities employ $12.1 \%$ of ICT professionals. Furthermore, it is worth mentioning that large entities provided various training to employees for the purpose of developing ICT skills during 2019. In large entities, 76.7\% of employees perform ICT functions, while in small entities $57.9 \%$ of external suppliers are in charge of ICT functions. 


\section{CONCLUSION}

The technological revolution of ICT and digital technologies have created environment where companies and the economy as a whole had to adopt a completely new business concept. Nevertheless, it is important to note that main goal of the company's business remained unchanged, which is to maximize profits. Adequate implementation of ICT and digital transformation that is done in a timely manner, can drastically affect productivity, time savings, efficiency of management of available resources, reduction and optimization of costs. From the aspect of the usage of ICT by companies, operating in the territory of the Republic of Serbia in the period from 2019 to 2020, there is an upward trend in growth according to all analysis. According to the data presented in the paper, when it comes to the existence of the Internet connection, all companies (100\%) included in the analysis have it. In addition, it is important to note that $77 \%$ of companies use a mobile internet connection through the portable devices, such as tablets, laptops and smartphones. A large number of observed companies (84.4\%) have a website, which indicates the existence of awareness and willingness of companies to create their own image and present themselves online.

Taking into consideration the changes that have happened during the period of global pandemic, which are referred to the period after displayed results, it is necessary to look at this aspect in the future. It is important to note that when it comes to changes in business processes due to pandemic, companies probably did not change fundamental business philosophy, which is profit maximization, but only changed the forms of business activities that embrace bigger (or complete) transition to digital business.

Given that the emergence and spread of the pandemic in the previous period has posed a great challenge to companies in terms of the ability to adapt to new circumstances, the question remains whether this situation in the long run will affect the ways in which companies conduct their business operations. Question remained to be answered whether companies in Republic of Serbia, when pandemic is over, will continue with the positive trend regarding digitalization or it will decide to return to the traditional ways of doing business which were standard before the pandemic.

\section{ACKNOWLEDGEMENTS}

This work is part of the project "Organizational and Information Support to the Quality Management System as a Key Factor in Increasing the Competitiveness of Our Companies and Faster Entry into the World and EU Market", no. 179001, financed by the Ministry of Education, Science and Technological Development of the Republic of Serbia.

\section{REFERENCES}

[1] Vlada Republike Srbije, "Srbija i Agenda 2030," 2021. [Online]. Available: https://rsjp.gov.rs/wpcontent/uploads/Agenda-UN-2030.pdf.

[2] R. Stankić and D. Stojković, "Upotreba informaciono-komunikacionih tehnologija poslovana preduzeća u Srbiji," Ekonomske ideje i praksa, vol. 27, no. 1, pp. 7-19, 2017.

[3] D. Dimitrijević and M. Janković, "InformacionoKomunikacione Tehnologije, Digitalna Ekonomija I Promena Industrijske Strukture," in Digitalna ekonomija i promena industrijske strukture, EasyChair Preprint no. 2871, 2020, pp. 1-5.

[4] D. Pavlovic, V. Vukmirović and I. Domazet, "Uticaj informaciono-komunikacionih tehnologija na tržištu rada mladi," in XXVI skup Trendovi razvoja: Inovacije u modernom poslovanju, 2020.

[5] M. K. M. O. A. P. M. Obradović, "E-Services: Efficiency and Use in Modern Business," in Sinteza 2020 - International Scientific Conference on Information Technology and Data Related Research, 2020.

[6] Inicijativa Digitalna Srbija, "Skener digitalne privrede," 2021. [Online]. Available: https://www.dsi.rs/ skener-digitalne-privrede-covid-19/.

[7] Startit, "Informatizacija, digitalizacija i digitalna transformacija - u čemu su razlike?," 2017. [Online]. Available: https://startit.rs/informatizacijadigitalizacija-i-digitalna-transformacija-u-cemusu-razlike/.

[8] H. Lajšić, "Sistemi poslovne inteligencije kao podrška unapređenju poslovnih procesa u organizacijama," Scientific journal of economics, vol. 1, no. 1, pp. 51-63, 2020.

[9] A. Sofronijević, V. Milićević and B. Ilić, "Strategijski pristup digitalnoj transformaciji poslovanja," Tehnika - Menadžment, vol. 67, no. 1, pp. 273-279, 2017.

[10] Minimax, "Blog," 2020. [Online]. Available: https:// www.minimax.hr/blog-zasto-uloziti-digitalizacijuposlovanja/. 
[11] Flexera, "Blog," 2021. [Online]. Available: https:// www.flexera.com/blog/cloud/cloud-computingtrends-2021-state-of-the-cloud-report/.

[12] Main Stream, "Cloud tehnologija: Glavne prednosti za kompanije," 2020. [Online]. Available: https://www.mainstream.rs/glavni-benefiti-cloudtehnologije-za-kompanije/.

[13] Republički zavod za statistiku, "Publikacije," 2020. [Online]. Available: https://publikacije.stat.gov.rs/ G2020/Pdf/G202016015.pdf. 